\title{
Porcine Fatty Acid Synthase Gene Polymorphisms Are Associated with Meat Quality and Fatty Acid Composition
}

\author{
Sang Wook Kim, Yang II Choi, Jung-Suck Choi, Jong Joo Kim¹, Bong Hwan Choi², \\ Tae Hun $\mathrm{Kim}^{2}$, and Kwan Suk Kim* \\ Department of Animal Science, Chungbuk National University, Cheongju 361-763, Korea \\ ${ }^{1}$ School of Biotechnology, Yeungnam University, Gyeongsan 712-749, Korea \\ ${ }^{2}$ Division of Animal Genomics and Bioinformatics, National Institute of Animal Science, Suwon 441-706, Korea
}

\begin{abstract}
We assessed the effects of single-nucleotide polymorphisms (SNPs) within the porcine fatty acid synthase (FASN) gene regarding meat quality and fatty acid composition in two pig populations: Korean native pigs (KNP) were crossed with Yorkshire (YS) $\mathrm{F}_{2}$, and KNP were crossed with Landrace (LR) $\mathrm{F}_{2}$. Direct DNA sequencing using eight KNP and eight YS pigs revealed two SNPs: c. 265C $>\mathrm{T}$ (silent) in exon 4 and c.6545A $>\mathrm{C}$ (Asn $\rightarrow$ His) in exon 39. The frequency of the two SNPs was analyzed using the polymerase chain reaction-restriction fragment length polymorphism method in seven pig breeds and their association with meat quality traits and fatty acid composition was studied. In the KNP $\times \mathrm{YS} \mathrm{F}_{2}$ population, both SNPs were significantly associated with the level of monounsaturated fatty acids, including palmitoleic (C16:1) and oleic acid $(\mathrm{C} 18: 1)(p<0.005)$. c.6545A $>\mathrm{C}$ was associated with intramuscular fat content in both populations. Our results indicate that variations in c. $265 \mathrm{C}>\mathrm{T}$ and c. $6545 \mathrm{~A}>\mathrm{C}$ of the pig $F A S N$ can be used to select animals with better fatty acid composition and meat quality. Moreover, KNP was a useful breed for identifying genetic factors affecting meat quality and fatty acid composition and for producing high quality pork.
\end{abstract}

Key words: fatty acid synthase, single nucleotide polymorphisms, meat quality, fatty acid composition, pig

\section{Introduction}

Various economically important traits in pigs have been genetically improved. As a result, current commercial pigs have very high growth rates, good feed conversion rates, and lean carcasses. Because consumers prefer high quality pork with good meat quality, there is a global trend toward high quality pork production, intramuscular fat (IMF) and marbling in particular have been considered the most important traits that correspond to meat quality. Now, the fatty acid composition of triglycerides in pork sirloin is becoming an important attribute that is related to human health (Wood et al., 2004a; Wood et al., 2004b). The fatty acid composition in pork is $60 \%$ saturated fatty acids (SFAs) and $40 \%$ unsaturated fatty acids (UFAs); the SFA content of pork is lower than that of beef (De et al., 2004). SFAs, including lauric acid (C12:0), myristic acid

\footnotetext{
*Corresponding author: Kwan Suk Kim, Department of Animal Science, Chungbuk National University, Cheongju 361-763, Korea. Tel: 82-43-261-2547, Fax: 82-43-273-2240, E-mail: Kwanskim@chungbuk.ac.kr
}

(C14:0), and palmitic acid (C16:0), have very harmful cardiovascular effects, although stearic acid (C18:0) does not. Monounsaturated fatty acids (MUFAs) have low melting points and improve the tenderness and flavor of pork (Melton et al., 1982; Smith et al., 2006). The MUFAs in pork, particularly oleic acid (C18:1), prevent oxidation and are very positively correlated with IMF, marbling, and meat quality traits (Cannata et al., 2010). In addition, palmitoleic acid (C16:1) intake is effective in reducing low-density lipoprotein (LDL) cholesterol and improves pancreatic function leading to increased insulin secretion (Nestel et al., 1994).

For the genetic improvement of pigs to produce highgrade pork, domestic animals with excellent meat quality and fatty acid composition traits should be carefully selected. Several studies have investigated candidate genes related to meat quality and fatty acid composition in pigs, and variation in the acetyl-coenzyme A carboxylase- $\alpha$ gene $(A C A C A)$ is reported to be a genetic marker of IMF and C18:1 content adjustment. In addition, variation in gastric inhibitory polypeptide (GIP) is also reported to be a genetic marker of $\mathrm{C} 16: 1$ and $\mathrm{C} 18: 0$ con- 
tent adjustment (Munoz et al., 2007; Gallardo et al., 2009). Several studies have reported that cattle FASN variation is a genetic factor that directly affects fatty acid content in beef, particularly oleic acid (C18:1), which influences flavor (Zhang et al., 2008; Bhuiyan et al., 2009; Abe et al., 2009; Kim et al., 2010a).

The FASN gene is located on pig chromosome 12 and encodes a complex enzyme that synthesizes fatty acids in adipose and liver tissues (Munoz et al., 2003). The pig FASN gene is known to be in the QTL region $(0-40 \mathrm{cM})$, which is associated with fatty acid formation in backfat, and it has been reported that variation in the FASN gene affects the gadoleic acid (C20:1, a MUFA) content of the fatty acid components in backfat (Munoz et al., 2007). In pigs, crossbreeding between different breeds is used for the selection and improvement of heterosis. Global representative pig breeds used for such improvements include Duroc, Landrace, Yorkshire and Berkshire. If these breeds are to be used to improve pork quality, their traits should be well understood. Compared with the Yorkshire breed, which is a Western breed, Korean native pigs (KNP) have smaller body sizes but thicker backfat, better fat deposits, better meat quality, and better marbling. Thus, several studies have been conducted in order to understand their molecular genetic background with the goal of producing high quality pork (Kim et al., 2007; Kim et al., 2009; Kim et al., 2010b; Li et al., 2010; Moon et al., 2009).

Therefore, the objectives of this study were to identify variations in porcine $F A S N$, to determine if the variations are genetic factors that affect meat quality and fatty acid composition, and then to evaluate the traits of different breeds with respect to the FASN gene.

\section{Materials and Methods}

\section{Animals and phenotypic traits analyzed}

DNA samples from Korean native pigs $(\mathrm{n}=48)$, Landrace $(n=24)$, Yorkshire $(n=24)$, Duroc $(n=24)$, and Berkshire $(n=24)$ pigs were obtained from the National Institute of Animal Science (NIAS) in Korea. A Korean native pig $(\mathrm{KNP}) \times$ Yorkshire (YS) population was produced at Chungbuk National University in order to identify QTLs and functional genes for economically important phenotypes (Kim et al., 2010b; Li et al., 2010). The meat quality traits include crude ash (C-ash), crude protein (Cpro), intramuscular fat (IMF), drip loss (DL), water-holding capacity (WHC), moisture, cooking loss (CL), shear force, $\mathrm{pH}$ at $24 \mathrm{~h}$ (24-h pH), color score, and total cholesterol. These traits were measured according to standard methods (Oh et al., 2008). The fatty acid profiles were measured based on a well-established method (Folch et al., 1957; Lepage and Roy, 1986). The composition ratios of the following fatty acids were calculated as described in Choi et al. (2008): myristic (C14:0), palmitic (C16:0), palmitoleic (C16:1), stearic (C18:0), oleic (C18:1), and linoleic acid (C18:2) (Table 1). NIAS reference families were constructed from a cross between KNP and Landrace (LR) sows. Five randomly selected KNP boars were mated with $10 \mathrm{LR}$ sows to produce the $\mathrm{F}_{1}$ animals. An $\mathrm{F}_{1}$ sire was randomly selected from each litter and mated with full-sib sows. Thus, 10 sires and 31 dams were used to produce $543 \mathrm{~F}_{2}$ animals (Kim et al., 2007). All phenotypic data are summarized at Table 1.

\section{Primer design and PCR}

The sequence of exon 4 in the FASN gene was analyzed using a previously described primer (Munoz et al., 2003). Primers for exons 38-41 of FASN were created in two steps. First, GenBank sequences from pig (AY954688), cattle (AF285607), human (AY451392), and goat (DQ915966) were obtained using the NCBI BLAST program (http:// blast.ncbi.nlm.nih.gov/), and primers in exon regions 3841 spanning pig FASN introns were designed using Oligo 6 software. These primer sets were then used to sequence the PCR product. Second, primers to amplify exonic regions were also designed within intronic sequences (introns 3841) (GenBank accesion number HQ651152). The oligonucleotide sequences, annealing temperatures, and PCR product sizes are presented in Table 2.

PCR amplifications were performed in a PTC-200 thermocycler (MJ Research, USA) using a standard protocol. The results of the PCR reaction were verified using $1.5 \%$ agarose gel electrophoresis.

\section{Sequencing, polymorphism identification, and geno- typing}

The DNA samples used in the sequence analysis were obtained from 16 pigs (8 KNP and 8 YS). A total of eight PCR products were sequenced with both forward and reverse primers. Sequencher software (Gene Codes, version 4.6, USA) was used to assemble the sequences and identify DNA polymorphisms. Polymorphic sites were analyzed for putative RFLPs using NEBcutter (http:// tools.neb.com/NEBcutter2/index.php). Genotyping of the putative RFLPs was performed on individual DNA samples from five different pig breeds: Duroc, LR, YS, Berkshire, and KNP. All restriction enzymes were supplied by New England BioLabs (Ipswich, USA), and restriction 
Table 1. Means and standard deviation of traits measured in pork from Korean native pig $\times$ Yorkshire (KY) cross F2 and Korean native pig $\times$ Landrace $(\mathrm{KL})$ cross $\mathrm{F} 2$

\begin{tabular}{|c|c|c|c|c|c|c|}
\hline \multirow{2}{*}{ Population } & \multicolumn{3}{|c|}{$\mathrm{KNP} \times \mathrm{YS}$ cross $\mathrm{F} 2$} & \multicolumn{3}{|c|}{$\mathrm{KNP} \times$ LR cross $\mathrm{F} 2$} \\
\hline & Mean & $\mathrm{SD}$ & $\mathrm{N}$ & Mean & $\mathrm{SD}$ & $\mathrm{N}$ \\
\hline \multicolumn{7}{|l|}{ Chemical composition $(\%)$} \\
\hline Moisture & 73.96 & 1.71 & 349 & - & - & - \\
\hline Crude Protein (C-pro) & 22.18 & 1.59 & 349 & 22.24 & 1.08 & 553 \\
\hline Intramuscular fat (IMF) & 2.49 & 1.45 & 349 & 2.15 & 2.15 & 553 \\
\hline Crude Ash (C-ash) & 1.05 & 0.13 & 349 & 1.04 & 0.14 & 553 \\
\hline \multicolumn{7}{|l|}{ Meat quality characteristics } \\
\hline Water holding capacity (WHC) (\%) & 58.03 & 6.34 & 349 & 58.14 & 5.18 & 553 \\
\hline 24-h pH & 5.63 & 0.25 & 349 & 5.63 & 0.22 & 553 \\
\hline Drip loss (DL) $(\%)$ & 5.11 & 1.81 & 349 & - & - & - \\
\hline Cooking loss (CL) (\%) & 32.26 & 3.53 & 349 & - & - & - \\
\hline Shear force $(\mathrm{kg})$ & 1.73 & 0.43 & 349 & - & - & - \\
\hline Cholesterol (mg/100g) & 142.02 & 84.38 & 349 & - & - & - \\
\hline \multicolumn{7}{|l|}{ Subjective evaluation* } \\
\hline Color (score) & 3.06 & 0.49 & 349 & - & - & - \\
\hline Texture (score) & 2.86 & 0.42 & 349 & - & - & - \\
\hline Myristic acid (C14:0) (\%) & 1.88 & 1.32 & 237 & - & - & - \\
\hline Palmitic acid (C16:0) (\%) & 21.11 & 2.61 & 237 & - & - & - \\
\hline Palmitoleic acid (C16:1) (\%) & 3.91 & 1.66 & 237 & - & - & - \\
\hline Stearic acid (C18:0) (\%) & 11.10 & 3.38 & 237 & - & - & - \\
\hline Oleic acid (C18:1) (\%) & 31.97 & 5.40 & 237 & - & - & - \\
\hline Linoleic acid (C18:2) (\%) & 12.90 & 6.40 & 237 & - & - & - \\
\hline Fatty acid composition & & & & & & \\
\hline
\end{tabular}

Texture, 1: extremely bad texture, 5 : very good texture

Meat color, 1 : very pale, 5 : very dark

5: very tender, very juicy, very intense

digestions were performed according to the manufacturer's recommendations. Digested PCR products were analyzed on $2.5-4 \%$ agarose gels, and each allele was scored manually. The restriction enzymes and polymorphic fragment sizes used for SNP genotyping are given in Table 2.

\section{Statistical analysis}

The genotypes of the FASN gene (c.265C $>\mathrm{T}$ and c. $6545 \mathrm{~A}>\mathrm{C}$ ) obtained from the testing materials were classified and their frequencies were calculated. In order to examine the genetic equilibrium between the populations (Hardy-Weinberg equilibrium, $P<0.05$ ), the significance was tested using the $\chi^{2}$-test.

Genotypic effects of variations in the FASN gene (c.265C $>\mathrm{T}$ and c. $6545 \mathrm{~A}>\mathrm{C}$ ) were estimated with mixed-model analysis using the SAS 9.1 Package/PC and the differences between genotypes were examined using least significant difference tests. The models used in the statistical analysis are as follows:

$$
\begin{aligned}
& \text { i) } \mathrm{KNP} \times \mathrm{YS} \operatorname{cross} \mathrm{F}_{2}(\mathrm{n}=343) \\
& \mathrm{Y}_{i j k l m \text { пр }}=\mu+\mathrm{S}_{i}+\mathrm{G}_{j}+\mathrm{D}_{k}+\mathrm{b}_{1} \mathrm{~L}_{l}+\mathrm{B}_{m}+\mathrm{D}_{n}+\mathrm{e}_{i j k l m n o} \text {, }
\end{aligned}
$$

where $\mathrm{Y}_{i j k l m n o p}$ is the observed value of carcass traits, $\mu$ is the mean of the samples, $\mathrm{S}_{i}$ is the effect of sex, $\mathrm{G}_{j}$ is the effect of genotype, $\mathrm{D}_{k}$ is the effect of slaughter date, $\mathrm{L}_{l}$ is the covariate of live weight, $\mathrm{b}_{1}$ is the regression coefficient of live weight, $\mathrm{B}_{m}$ is the covariate of body length, $\mathrm{D}_{n}$ is the random effect of age at slaughter and $\mathrm{e}_{i j k l m n o}$ is the random error.

ii) $\mathrm{KNP} \times \operatorname{LR}$ cross $\mathrm{F}_{2}(\mathrm{n}=480)$

$$
\mathrm{Y}_{i j k l m \text { по }}=\mu+\mathrm{S}_{i}+\mathrm{G}_{j}+\mathrm{D}_{k}+\mathrm{b}_{l} \mathrm{~L}_{l}+\mathrm{D}_{m}+\mathrm{e}_{i j k l m n},
$$

where $Y_{i j k l m o}$ is the observed value of carcass traits, $\mu$ is the mean of the samples, $\mathrm{S}_{i}$ is the effect of sex, $\mathrm{G}_{j}$ is the effect of genotype, $\mathrm{D}_{k}$ is the effect of slaughter date, $\mathrm{L}_{l}$ is the covariate of live weight, $\mathrm{b}_{1}$ is the regression coefficient of live weight, $\mathrm{D}_{m}$ is the random effect of age at slaughter and $\mathrm{e}_{i j k l m n}$ is the random error. Body length was excluded from the model due to lack of phenotypic data 
Table 2. PCR primers and conditions used for amplification and sequencing, and restriction enzymes used for SNP genotyping

\begin{tabular}{|c|c|c|c|c|c|c|c|}
\hline \multirow[b]{2}{*}{ Oligonucleotide } & \multirow{2}{*}{$\begin{array}{l}\text { GenBank } \\
\text { no }\end{array}$} & Primer & \multirow{2}{*}{$\begin{array}{l}\text { Annealing } \\
\text { temp. }\end{array}$} & \multirow{2}{*}{$\begin{array}{l}\text { Product } \\
\text { size }\end{array}$} & \multirow{2}{*}{$\begin{array}{c}\text { SNP } \\
\text { detection }\end{array}$} & \multirow{2}{*}{$\begin{array}{l}\text { Restriction } \\
\text { enzyme }\end{array}$} & \multirow{2}{*}{$\begin{array}{c}\text { Size (bp) of } \\
\text { the allelic } \\
\text { polymorphism }\end{array}$} \\
\hline & & $\begin{array}{l}\text { Forward }\left(5^{\prime} \rightarrow 3^{\prime}\right) \\
\text { Reverse }\left(5^{\prime} \rightarrow 3^{\prime}\right)\end{array}$ & & & & & \\
\hline FASN-exon4* & AY183428 & $\begin{array}{l}\text { ATCAACCCTGCTTCCCTTCGTG } \\
\text { CGCGCTGGCAGCCTATCAT }\end{array}$ & 58 & 130 & $\begin{array}{l}\text { c. } 265 \mathrm{C}>\mathrm{T} \\
\text { (Silent) }\end{array}$ & Fnu4H I & 120,66 \\
\hline FASN-intron38 & AF285607 & $\begin{array}{l}\text { GGGCGTCGTCCTGGAGACCAT } \\
\text { GCTGCCGCACCTCCG }\end{array}$ & 60 & 527 & & & \\
\hline FASN-intron39 & AF285607 & $\begin{array}{l}\text { GGGCCTGGACTCGCTCAT } \\
\text { ACGGTGATGGAGCCCTCGATG }\end{array}$ & 57 & 312 & $\begin{array}{l}\text { c. } 6545 \mathrm{~A}>\mathrm{C} \\
\text { (Asn- }>\text { His) }\end{array}$ & BssS I & 312,161 \\
\hline FASN-intron 40 & AF285607 & $\begin{array}{l}\text { GGGGCCTTACCGCATCGC } \\
\text { GCAGCCGGGGGTCATCTTAGC }\end{array}$ & 57 & 265 & & & \\
\hline FASN-intron 41 & AF285607 & $\begin{array}{l}\text { TGCAGCAGTTCACCGACATGG } \\
\text { TTGCCGTCGCACACCT }\end{array}$ & 58 & 295 & & & \\
\hline FASN-exon39 & AF285607 & $\begin{array}{l}\text { CGGCGACTCCCACATCC } \\
\text { GAAGGTGTGTGAGCCGTCGAA }\end{array}$ & 58 & 507 & & & \\
\hline FASN-exon40 & AF285607 & $\begin{array}{l}\text { CCCGAGGGGCCTTACCGCATC } \\
\text { GAAGGAGCGAGCGGCGAA }\end{array}$ & 60 & 556 & & & \\
\hline FASN-exon41 & AF285607 & $\begin{array}{l}\text { CCCGAGGGGCCTTACCGCATC } \\
\text { GAAGGAGCGAGCGGCGAA }\end{array}$ & 60 & 556 & & & \\
\hline
\end{tabular}

* Primer is referenced from Munos et al., 2003.

All primers were based on the porcine $F A S N$ sequence, NCBI GenBank accession number AF285607.

on this trait for KNP $\times$ LR cross $\mathrm{F}_{2}$.

iii) Combined $(\mathrm{KNP} \times \mathrm{YS})+(\mathrm{KNP} \times \mathrm{LR})$ population $(\mathrm{n}=822)$

$$
\mathrm{Y}_{i j k l m n o}=\mu+\mathrm{S}_{i}+\mathrm{G}_{j}+\mathrm{D}_{k}+\mathrm{b}_{l} \mathrm{~L}_{l}+\mathrm{D}_{m}+\mathrm{e}_{i j k l m n},
$$

where $\mathrm{Y}_{i j k l m n o}$ is the observed value of carcass traits, $\mu$ is the mean of the samples, $S_{i}$ is the effect of sex, $G_{j}$ is the effect of genotype, $\mathrm{D}_{k}$ is the effect of slaughter date, $\mathrm{L}_{l}$ is the covariate of live weight, $b_{l}$ is the regression coefficient of live weight, $\mathrm{D}_{m}$ is the random effect of age at slaughter and $\mathrm{e}_{i j k l m n}$ is the random error. The least-square means of the genotypes estimated using these equations were tested using the $t$-test, and the phenotypic differences between haplotypes were tested using contrast tests.

The degree of linkage disequilibrium (LD) between variations in the $F A S N$ gene, c. $265 \mathrm{C}>\mathrm{T}$ (silent) and c.6545A $>\mathrm{C}$ (Asn $\rightarrow$ His), was estimated using the HaploView software package (Barrett et al., 2005), and the $\mathrm{D}^{\prime}$ and $\mathrm{r}^{2}$ values between the variations were estimated using the method described by Stephens et al. (2001).

The association of three haplotype classes with collected economic traits was also analyzed using the same model used to analyze the effects of individual genotypes.

\section{Results}

\section{SNP detection and genotyping}

The pig FASN sequence, including exon 4 and exons 38-41 sequence (GenBank accession number HQ651152), spanning four introns, was obtained using eight primer sets. Two SNPs were found, both of which have been previously reported: c. $265 \mathrm{C}>\mathrm{T}$ (silent) in exon 4 and c.6545A $>\mathrm{C}$ (Asn $\rightarrow$ His) in exon 39 (Munoz et al., 2007). These polymorphisms in the pig FASN gene were analyzed using PCR-RFLP methods; c. 265C $>$ T with Fnu4HI and c. $6545 \mathrm{~A}>\mathrm{C}$ with BssSI. For the c. $265 \mathrm{C}>\mathrm{T}$ polymorphism, restriction digestion yielded fragments of 120 and $10 \mathrm{bp}$ when the variation was the CC genotype; 120, 66, 54, and $10 \mathrm{bp}$ for the CT genotype; and 66, 64, and $10 \mathrm{bp}$ for the TT genotype. For the c. $6545 \mathrm{~A}>\mathrm{C}$ polymorphism, restriction digestion yielded a fragment of $312 \mathrm{bp}$ when the variation was the AA genotype; 312, 161, and $151 \mathrm{bp}$ for the AC genotype; and 161 and 151 bp for the CC genotype (Table 2).

\section{FASN amino acid alignment among mammalian species}

The putative porcine FASN amino acid sequence encoded by exons 39-42 (AAX55638) was compared to that of human, goat, and cattle (Fig. 1). One of the amino acid positions mutated in the porcine sequence, His2206Asn is 


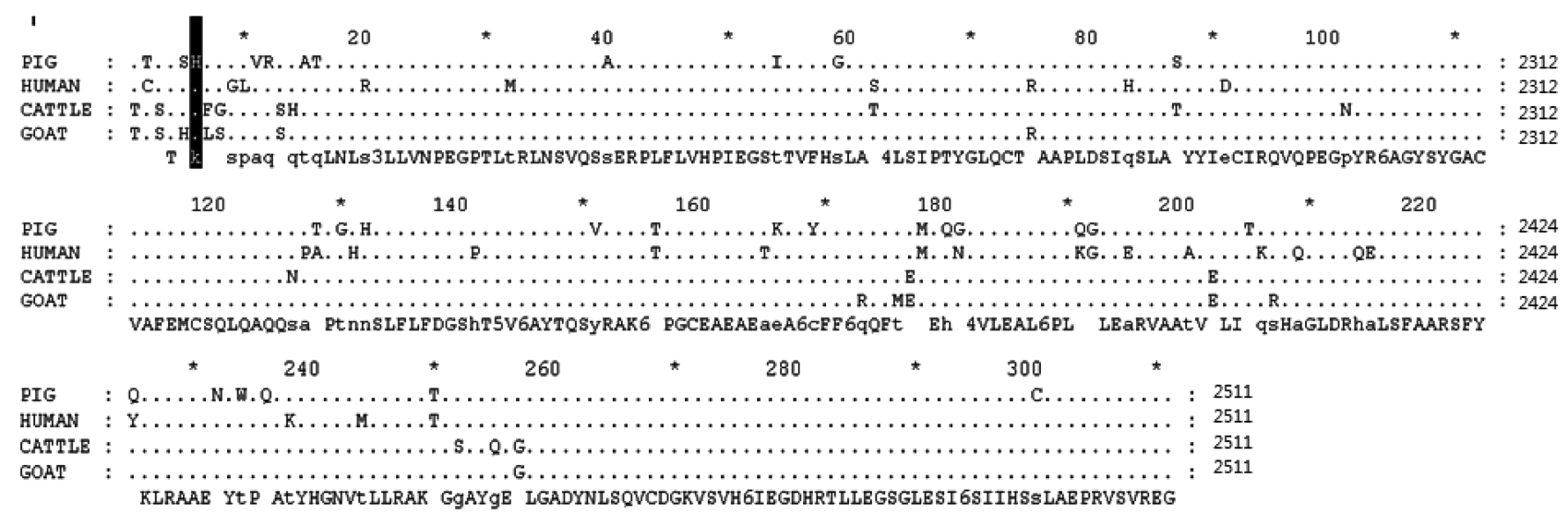

Fig. 1. The putative bovine FASN amino acid sequences encoded by exons 39-42 (AAX55638) compared with those in humans, goats, and cattle. Sequences were aligned using Blast (http://www.ncbi.nlm.nih.gov/blast/Blast). One of the mutated amino acid positions, 2206 ( $\mathrm{H}$ or $\mathrm{N})$, is represented by a black bar.

Table 3. Genotypes and minor allele frequencies of $2(\mathrm{c} .265 \mathrm{C}>\mathrm{T}$ and $\mathrm{c} .6545 \mathrm{~A}>\mathrm{C})$ polymorphisms in the $F A S N$ gene from 7 pig populations

\begin{tabular}{|c|c|c|c|c|c|c|c|c|c|}
\hline \multirow{2}{*}{$\begin{array}{c}\text { SNP } \\
\text { Position }\end{array}$} & \multirow[t]{2}{*}{ AA change } & \multirow{2}{*}{$\begin{array}{c}\begin{array}{c}\text { Population } \\
\text { (N. of pig) }\end{array} \\
\text { Landrace }(n=24)\end{array}$} & \multicolumn{3}{|c|}{ Genotype (N. of pig) } & \multirow{2}{*}{$\begin{array}{c}\begin{array}{c}\text { Allele } 1 \\
\text { frequency }\end{array} \\
0.44\end{array}$} & \multirow{2}{*}{$\begin{array}{c}\begin{array}{c}\text { Allele } 2 \\
\text { frequency }\end{array} \\
0.56\end{array}$} & \multirow{2}{*}{$\begin{array}{c}\begin{array}{c}\text { Heterozy- } \\
\text { gosity }\end{array} \\
0.492\end{array}$} & \multirow{2}{*}{$\begin{array}{c}\begin{array}{c}\text { HWE } \\
\text { P-value }\end{array} \\
0.4183\end{array}$} \\
\hline & & & $\mathrm{CC}(6)$ & CT (15) & TT (3) & & & & \\
\hline & & Yorkshire $(n=24)$ & $\mathrm{CC}(5)$ & CT (14) & TT (5) & 0.50 & 0.50 & 0.500 & 0.7595 \\
\hline & & Duroc $(n=24)$ & CC (24) & $\mathrm{CT}(0)$ & TT $(0)$ & 1 & 0 & 0 & 1.0000 \\
\hline \multirow[t]{7}{*}{ c. $265 \mathrm{C}>\mathrm{T}$} & Silent & Berkshire $(n=24)$ & CC (17) & CT (7) & TT $(0)$ & 0.85 & 0.15 & 0.249 & 0.0912 \\
\hline & & $\mathrm{KNP}(\mathrm{n}=48)$ & CC (47) & CT (1) & $\mathrm{TT}(0)$ & 0.99 & 0.01 & 0.021 & 1.0000 \\
\hline & & $\mathrm{KY}(\mathrm{n}=342)$ & CC (159) & CT (163) & TT (20) & 0.70 & 0.30 & 0.204 & 0.5679 \\
\hline & & $\mathrm{KL}(\mathrm{n}=343)$ & $\mathrm{CC}(270)$ & $\mathrm{AG}(67)$ & TT (6) & 0.90 & 0.10 & 0.417 & 0.0118 \\
\hline & & Yorkshire $(n=21)$ & $\mathrm{AA}(3)$ & CA (11) & $\mathrm{CC}(7)$ & 0.40 & 0.60 & 0.482 & 1.0000 \\
\hline & & Landrace $(\mathrm{n}=20)$ & $\mathrm{AA}(4)$ & CA (12) & $\mathrm{CC}(4)$ & 0.50 & 0.50 & 0.500 & 0.7374 \\
\hline & & Duroc $(n=24)$ & $\mathrm{AA}(5)$ & CA (14) & $\mathrm{CC}(5)$ & 0.50 & 0.50 & 0.500 & 0.7595 \\
\hline \multirow[t]{4}{*}{ c. $6545 \mathrm{~A}>\mathrm{C}$} & Asn->His & Berkshire $(n=22)$ & AA (10) & CA (11) & $\mathrm{CC}(1)$ & 0.73 & 0.27 & 0.416 & 0.7692 \\
\hline & & $\mathrm{KNP}(\mathrm{n}=48)$ & AA (48) & $\mathrm{CA}(0)$ & $\mathrm{CC}(0)$ & 1 & 0 & 0 & 1.0000 \\
\hline & & $\mathrm{KY}(\mathrm{n}=326)$ & AA (127) & CA (172) & CC (27) & 0.65 & 0.35 & 0.408 & 0.0571 \\
\hline & & $\mathrm{KL}(\mathrm{n}=480)$ & AA (264) & CA (174) & CC (42) & 0.73 & 0.27 & 0.453 & 0.0641 \\
\hline
\end{tabular}

KY: Korean Native pig $\times$ Yorkshire cross F2 pigs

KL: Korean Native pig $\times$ Landrace cross F2 pigs

shown in a black box in Fig. 1; in all the other species, amino acid position 2206 was fixed to lysine (K) (Fig. 1).

\section{Comparison of FASN genotype frequencies among several pig breeds}

The genotype frequencies of c.265C $>\mathrm{T}$ (exon 4 - silent) and c. $6545 \mathrm{~A}>\mathrm{C}$ (exon $39-\mathrm{Asn} \rightarrow \mathrm{His}$ ) variation in the FASN gene from different pig breeds are summarized in Table 4. The frequency of the $\mathrm{C}$ allele in c. $265 \mathrm{C}>\mathrm{T}$ was 0.44 and 0.50 in the Landrace and Yorkshire populations, respectively. However, the $\mathrm{C}$ allele frequency was 1, 0.85, and 0.99 in the Duroc, Berkshire and Korean native pig populations, respectively. For the second polymorphism, c. $6545 \mathrm{~A}>\mathrm{C}$, located in exon 39 , the A allele frequency was $0.40,0.50$ and 0.50 in the Landrace, Yorkshire, and Duroc populations, respectively. However, the A allele frequency was 0.73 and 1 in the Berkshire and Korean native pig populations, respectively (Table 3 ).

\section{Single polymorphism linkage analyses}

The association of the two polymorphisms in the pig FASN gene, c. 265C $>\mathrm{T}$ (exon 4 - silent) and c.6545A $>\mathrm{C}$ (exon 39 - Asn $\rightarrow$ His), with traits related to meat quality and fatty acid composition was analyzed using (1) the $\mathrm{KNP} \times \mathrm{YS} \mathrm{F}_{2}$ population $(\mathrm{n}=347)$, and $(2)$ the KNP $\times$ LR $F_{2}$ population $(n=553)$ (Table 4$)$. There was a significant association between the c.265C $>\mathrm{T}$ genotype located in exon 4 and both C-pro and flavor in the KNP $\times \mathrm{YS} \mathrm{F}_{2}$ 
Table 4. Association of 2 FASN gene polymorphism (c.265C $>$ T and c.6545A $>$ C) genotypes with five meat quality traits from KNP $\times$ YS and KNP $\times$ LR cross F2 pigs

\begin{tabular}{|c|c|c|c|c|c|c|c|c|c|c|c|c|c|}
\hline \multirow{3}{*}{ Gene } & \multirow{3}{*}{$\begin{array}{l}\text { Phenotypic } \\
\text { trait }\end{array}$} & & $\begin{array}{l}x \text { YS cro } \\
=342 \text { and } 3\end{array}$ & & \multirow{3}{*}{ P-value } & \multicolumn{3}{|c|}{$\begin{array}{c}\text { KNP x LR cross F2 } \\
(n=343 \text { and } 480)\end{array}$} & \multirow{3}{*}{ P-value } & Combin & $\begin{array}{l}\mathrm{KY} \text { and } \mathrm{KL} \\
=685 \text { and } 8 \mathrm{c}\end{array}$ & opulation & \multirow{3}{*}{ P-value } \\
\hline & & \multicolumn{3}{|c|}{ Genotypic least squares means (SE) } & & \multicolumn{3}{|c|}{ Genotypic least squares means (SE) } & & \multicolumn{3}{|c|}{ Genotypic least squares means (SE) } & \\
\hline & & 11 & 12 & 22 & & 11 & 12 & 22 & & 11 & 12 & 22 & \\
\hline \multirow{14}{*}{$\begin{array}{c}\text { FASN } \\
\text { Exon4 } \\
\text { c. } 265 \mathrm{C}>\mathrm{T}\end{array}$} & & $\mathrm{CC}$ & $\mathrm{CT}$ & TT & \multirow[b]{2}{*}{0.0291} & $\mathrm{CC}$ & $\mathrm{CT}$ & TT & \multirow[b]{2}{*}{0.7455} & $\mathrm{CC}$ & CT & TT & \multirow[b]{2}{*}{0.9610} \\
\hline & C-pro & $\begin{array}{c}22.043 \\
(0.116)^{\mathrm{a}}\end{array}$ & $\begin{array}{c}22.440 \\
(0.116)^{\mathrm{a}}\end{array}$ & $\begin{array}{c}21.892 \\
(0.304)^{\mathbf{b}}\end{array}$ & & $\begin{array}{l}22.156 \\
(0.148\end{array}$ & $\begin{array}{l}22.205 \\
(0.205)\end{array}$ & $\begin{array}{l}21.775 \\
0.512\end{array}$ & & $\begin{array}{l}22.196 \\
(0.101)\end{array}$ & $\begin{array}{l}22.205 \\
(0138)\end{array}$ & 22.060 & \\
\hline & & $\mathrm{CC}$ & CT & TT & & $\mathrm{CC}$ & CT & TT & & $\mathrm{CC}$ & CT & TT & \\
\hline & IMF & 2.335 & 2.730 & 2.875 & 0.0686 & 2.250 & 2.131 & 2.703 & 0.0701 & 2.409 & 2.258 & 2.749 & 0.6393 \\
\hline & & $(0.131)$ & $(0.132)$ & $(0.348)$ & & $(0.183)$ & $(0.250)$ & $(0.236)$ & & $(0.120)^{\mathrm{a}}$ & $(0.164)^{\mathrm{a}}$ & $(0.564)^{\mathbf{b}}$ & \\
\hline & & $\mathrm{CC}$ & $\mathrm{CT}$ & TT & & $\mathrm{CC}$ & $\mathrm{CT}$ & TT & & $\mathrm{CC}$ & $\mathrm{CT}$ & TT & \\
\hline & C-Ash & 1.068 & 1.066 & 0.988 & 0.0352 & 1.016 & 1.056 & 0.996 & 0.1924 & 1.040 & 1.074 & 1.031 & 0.2537 \\
\hline & & $(0.011)$ & $(0.011)$ & $(0.029)$ & & $(0.018$ & $(0.026$ & $(0.065$ & & $(0.011)$ & $(0.015)$ & $(0.052)$ & \\
\hline & & $\mathrm{CC}$ & CT & TT & & $\mathrm{CC}$ & CT & TT & & $\mathrm{CC}$ & CT & TT & \\
\hline & WHC & 58.586 & 58.066 & 56.511 & 0.1200 & 59.140 & 57.128 & 55.144 & 0.0150 & 58.980 & 57.243 & 55.390 & 0.0164 \\
\hline & & $(0.369)$ & $(0.371)$ & $(0.966)$ & & $\left(0.671^{\mathrm{a}}\right.$ & $(0.930)^{\mathbf{a}, \mathbf{b}}$ & $(2.318)^{\mathbf{b}}$ & & $(0.389)^{\mathbf{a}}$ & $(0.531)^{\mathbf{a}, \mathbf{b}}$ & $(1.825)^{\mathbf{b}}$ & \\
\hline & & $\mathrm{CC}$ & $\mathrm{CT}$ & TT & & $\mathrm{CC}$ & $\mathrm{CT}$ & TT & & $\mathrm{CC}$ & $\mathrm{CT}$ & TT & \\
\hline & 24-h pH & 5.635 & 5.636 & 5.598 & 0.3807 & 5.625 & 5.552 & 5.534 & 0.1005 & 5.654 & 5.587 & 5.553 & 0.0237 \\
\hline & & $(0.010)$ & $(0.010)$ & $(0.026)$ & & $(0.029)$ & $(0.041)$ & $(0.103)$ & & $(0.014)$ & $(0.019)$ & $(0.068)$ & \\
\hline \multirow{15}{*}{$\begin{array}{c}\text { FASN } \\
\text { Exon39 } \\
\text { c. } 6545 \mathrm{~A}>\mathrm{C}\end{array}$} & & AA & CA & $\mathrm{CC}$ & \multirow{3}{*}{0.2216} & AA & CA & $\mathrm{CC}$ & \multirow{3}{*}{0.0926} & AA & CA & $\mathrm{CC}$ & \multirow{3}{*}{0.0271} \\
\hline & C-pro & 22.137 & 22.341 & 21.906 & & 22.259 & 21.935 & 22.202 & & 22.335 & 21.970 & 22.276 & \\
\hline & & $(0.126)$ & $(0.112)$ & $(0.261)$ & & $(0.158)$ & $(0.173)$ & $(0.252)$ & & $(0.105)^{\mathrm{a}}$ & $(0.107)^{\mathbf{b}}$ & $(0.221)^{\mathbf{b}}$ & \\
\hline & & AA & CA & $\mathrm{CC}$ & \multirow{3}{*}{0.0390} & AA & $\mathrm{CA}$ & $\mathrm{CC}$ & \multirow{3}{*}{0.0107} & AA & CA & $\mathrm{CC}$ & \multirow{3}{*}{0.0487} \\
\hline & IMF & 2.731 & 2.712 & 2.324 & & 2.260 & 2.311 & 1.956 & & 2.384 & 2.393 & 2.273 & \\
\hline & & $(0.295)^{\mathbf{a}}$ & $(0.126)^{\mathrm{a}}$ & $(0.141)^{\mathbf{b}}$ & & $(0.199)^{\mathbf{a}}$ & $(0.219)^{\mathbf{a}}$ & $(0.317)^{\mathbf{b}}$ & & $(0.126)^{a}$ & $(0.129)^{\mathbf{a}}$ & $(0.265)^{\mathbf{b}}$ & \\
\hline & & AA & CA & $\mathrm{CC}$ & \multirow{3}{*}{0.0448} & AA & $\mathrm{CA}$ & $\mathrm{CC}$ & \multirow{3}{*}{0.9929} & AA & CA & $\mathrm{CC}$ & \multirow{3}{*}{0.7217} \\
\hline & C-Ash & 1.067 & 1.069 & 1.003 & & 1.020 & 1.027 & 1.018 & & 1.050 & 1.057 & 1.035 & \\
\hline & & $(0.011)^{a}$ & $(0.010)^{\mathbf{a}}$ & $(0.024)^{\mathbf{b}}$ & & $(0.020)$ & $(0.022)$ & $(0.032)$ & & $(0.011)$ & $(0.011)$ & $(0.024)$ & \\
\hline & & $\mathrm{AA}$ & $\mathrm{CA}$ & $\mathrm{CC}$ & \multirow{3}{*}{0.2653} & AA & $\mathrm{CA}$ & $\mathrm{CC}$ & \multirow{3}{*}{0.0192} & $\mathrm{AA}$ & $\mathrm{CA}$ & $\mathrm{CC}$ & \multirow{3}{*}{0.0406} \\
\hline & WHC & 58.723 & 58.042 & 57.400 & & 59.422 & 58.674 & 56.230 & & 58.833 & 57.859 & 56.541 & \\
\hline & & $(0.409)$ & $(0.365)$ & $(0.853)$ & & $(0.723)^{\mathrm{a}}$ & $(0.791)^{\mathbf{a}, \mathbf{b}}$ & $(1.153)^{\mathbf{b}}$ & & $(0.408)^{a}$ & $(0.416)^{\mathbf{a}, \mathbf{b}}$ & $(0.858)^{\mathbf{b}}$ & \\
\hline & & AA & $\mathrm{CA}$ & $\mathrm{CC}$ & & AA & $\mathrm{CA}$ & $\mathrm{CC}$ & & AA & $\mathrm{CA}$ & $\mathrm{CC}$ & \\
\hline & 24-h pH & 5.638 & 5.637 & 5.593 & 0.1751 & 5.632 & 5.608 & 5.538 & 0.1692 & 5.647 & 5.619 & 5.555 & 0.0355 \\
\hline & & $(0.010)$ & $(0.009)$ & $(0.022)$ & & $(0.032)$ & $(0.0395)$ & $(0.051)$ & & $(0.015)^{a}$ & $(0.015)^{\mathrm{a}}$ & $(0.031)^{\mathbf{b}}$ & \\
\hline
\end{tabular}

Significance level: ${ }^{\mathrm{a}, \mathrm{b}} 0.05 ;{ }^{\mathrm{c}, \mathrm{d}} 0.01{ }^{\mathrm{e}, \mathrm{f}} 0.005$ 
Table 5. Association of 2 FASN gene polymorphism (c.265C $>$ T and c.6545A $>$ C) genotypes with meat quality and fatty acid composition traits from KNP $\times$ YS cross F2 pigs

\begin{tabular}{|c|c|c|c|c|c|}
\hline \multirow{3}{*}{ Gene } & \multirow{3}{*}{$\begin{array}{l}\text { Phenotypic } \\
\text { trait }\end{array}$} & \multicolumn{3}{|c|}{ KNP x YS cross F2 (n=342 and 326) } & \multirow{3}{*}{ P-value } \\
\hline & & \multicolumn{3}{|c|}{ Genotypic least squares means ( SE ) } & \\
\hline & & 11 & 12 & 22 & \\
\hline \multirow{8}{*}{$\begin{array}{c}\text { FASN } \\
\text { Exon4 } \\
\text { c. } 265 \mathrm{C}>\mathrm{T}\end{array}$} & Shearforce & CC: $1758.95(36.704)$ & CT: 1767.28 (36.904) & TT: $1531.91(97.253)$ & 0.0701 \\
\hline & Flavor & CC: $2.883(0.033)^{\mathrm{a}}$ & CT $2.994(0.034)^{\mathbf{b}}$ & TT: $2.849(0.089)^{\mathbf{b}}$ & 0.0437 \\
\hline & $\mathrm{C} 14: 0$ & CC: $2.008(0.133)$ & CT $1.721(0.142)$ & TT: $1.725(0.343)$ & 0.3273 \\
\hline & $\mathrm{C} 16: 0$ & $\mathrm{CC}: 21.175(0.257)$ & CT $21.017(0.274)$ & TT: 19.595 (0.664) & 0.0884 \\
\hline & $\mathrm{C} 16: 1$ & CC: $5.544(0.224)^{\mathbf{e}}$ & CT $3.704(0.175)^{f}$ & TT: $3.725(0.154)^{\mathbf{f}}$ & 0.0002 \\
\hline & $\mathrm{C} 18: 0$ & CC: $10.789(0.359)$ & CT $11.517(0.383)$ & TT: 9.995 (0.927) & 0.1855 \\
\hline & C18:1 & CC: $32.828(0.845)^{\mathbf{c}}$ & CT $33.180(0.515)^{\mathbf{c}}$ & TT: $30.891(0.482)^{\mathbf{d}}$ & 0.0060 \\
\hline & $\mathrm{C} 18: 2$ & CC: $13.808(0.356)$ & CT $12.822(0.380)$ & TT: $12.838(0.920)$ & 0.1606 \\
\hline \multirow{8}{*}{$\begin{array}{c}\text { FASN } \\
\text { Exon39 } \\
\text { c. } 6545 \mathrm{~A}>\mathrm{C}\end{array}$} & Shearforce & AA: $1765.72(39.513)^{\mathbf{a}}$ & CA: $1773.44(35.075)^{\mathbf{a}}$ & CC: $1542.68(81.794)^{\mathbf{b}}$ & 0.0309 \\
\hline & Flavor & AA: $2.888(0.032)^{\mathbf{a}}$ & CA: $2.983(0.028)^{\mathbf{b}}$ & CC: $2.854(0.071)^{\mathbf{a}, \mathbf{b}}$ & 0.1006 \\
\hline & $\mathrm{C} 14: 0$ & AA: $2.082(0.149)$ & CA: $1.732(0.125)$ & CC: $1.700(0.322)$ & 0.1812 \\
\hline & C16:0 & AA: 21.197 (0.289) & CA: $21.035(0.243)$ & CC: $19.728(0.625)$ & 0.1014 \\
\hline & C16:1 & AA: $5.290(0.402)^{\mathbf{e}}$ & CA: $3.654(0.156)^{f}$ & CC: $3.814(0.186)^{f}$ & 0.0008 \\
\hline & C18:0 & AA: 10.727 (0.404) & CA: $11.414(0.340)$ & CC: 10.105 (0.873) & 0.2218 \\
\hline & C18:1 & AA: $32.902(0.868)^{\mathbf{e}}$ & CA: $32.929(0.455)^{\mathbf{e}}$ & CC: $30.562(0.541)^{\mathbf{f}}$ & 0.0036 \\
\hline & $\mathrm{C} 18: 2$ & AA: $13.801(0.402)$ & CA: $13.032(0.338)$ & CC: $12.860(0.868)$ & 0.3067 \\
\hline
\end{tabular}

Significance level: ${ }^{\mathrm{a}, \mathrm{b}} 0.05 ;^{\mathrm{c}, \mathrm{d}} 0.01 ;^{\mathrm{e}, \mathrm{f}} 0.005$

population $(p<0.05)$, and significant effects on WHC were observed in the $\mathrm{KNP} \times \mathrm{LR} \mathrm{F}_{2}$ population $(p<0.05)$. It was apparent that animals with the CC genotype had better WHC values than animals with a CT or TT genotype. In addition, we combined the KNP $\times \mathrm{YS}_{2}$ and $\mathrm{KNP} \times \mathrm{LR} \mathrm{F}_{2}$ populations to analyze five meat quality measurements in the combined population: C-pro, IMF, $\mathrm{C}$-ash, WHC and 24-h pH, which have common phenotypic data between them. Of the five meat quality measurements in the combined population, WHC and 24-h $\mathrm{pH}$ showed significant differences; individuals with the CC genotype had better WHC and higher 24-h pH than individuals with a CT or TT genotype (Table 4). Data from the fatty acid composition analysis of the KNP $\times$ YS $\mathrm{F}_{2}$ population showed highly significant effects on $\mathrm{C} 16: 1$ and C18:1 ( $p=0.0002$ and 0.0060, respectively) (Table 5). Animals with a CC or CT genotype had much higher C16:1 and C18:1 (MUFAs) contents than individuals with the TT genotype.

A significant association was also observed between the c.6545A $>\mathrm{C}$ genotype in exon 39 and IMF, $\mathrm{C}$-ash and shear force in the KNP $\times$ YS $\mathrm{F}_{2}$ population $(p<0.05)$. IMF, $\mathrm{C}$-ash and shear force were higher in individuals with an AA or CA genotype than in those with the CC genotype. In the $\mathrm{KNP} \times \mathrm{LR} \mathrm{F}_{2}$ population, the c.6545A $>\mathrm{C}$ genotype showed significant linkage with IMF and WHC $(p<0.05)$. Again, animals with an AA or CA geno- type had higher IMF and shear force than those with the CC genotype. Of the five meat quality traits in the combined population, C-pro, IMF, WHC, and 24-h pH showed a significant association $(p<0.05)$. Animals with an AA or CA genotype had higher IMF and better WHC than those with the CC genotype (Table 4). The fatty acid composition analysis of the $\mathrm{KNP} \times \mathrm{YS} \mathrm{F}_{2}$ population had highly significant effects on $\mathrm{C} 16: 1$ and $\mathrm{C} 18: 1 \quad(P=$ 0.0008 and 0.0036, respectively); individuals with an AA or CA genotype had higher C18:1 contents than individuals with the $\mathrm{CC}$ genotype (Table 5).

\section{Discussion}

It has been reported that porcine $F A S N$, located on chromosome 12 , is a candidate gene the fatty acid levels in meats (Munoz et al., 2003). It has also been reported that a total of 10 SNPs were detected in the coding region of the pig FASN gene; three of these-c.1254A $>\mathrm{G}(\mathrm{Arg} \rightarrow$ Gln), c.3189T $>\mathrm{C}(\mathrm{Thr} \rightarrow \mathrm{Ile})$ and c.6545A $>\mathrm{C}(\mathrm{Asn} \rightarrow \mathrm{His})-$ are missense SNPs that change amino acids, but the phenotypic association has only been established for the c. $1254 \mathrm{~A}>\mathrm{G}(\mathrm{Arg} \rightarrow \mathrm{Gln})$ SNP, which adversely affects C20:1 in backfat when it is an A allele (Arg); (Munoz et al., 2007). In this study, two SNPs, c.265C $>\mathrm{T}$ (Silent) and c. $6545 \mathrm{~A}>\mathrm{C}$ (Asn $\rightarrow$ His), were rediscovered and characterized in several commercially important pig breeds and 
their association with fatty acid composition and meat quality was studied. The c.6545A $>\mathrm{C}$ (Asn $\rightarrow$ His) variation in exon 39 was found at amino acid position 2207 in pig FASN; although it is $\mathrm{H}$ in pigs, it is fixed as $\mathrm{K}$ in cattle, human, and goat (Fig. 1).

FASN is a complex homodimeric enzyme that regulates the de novo synthesis of long-chain fatty acids in mammals and catalyzes the formation of 16-carbon fatty acids from acetyl-coenzyme A to malonyl-coenzyme A (Chakravarty et al., 2004). This synthesis involves a conserved set of chemical reactions for the cyclic-step elongation of activated precursors by two carbon units (Smith et al., 2003). The growing fatty acid is attached to an acyl carrier protein (ACP) throughout its synthesis and is generally released by a thioesterase (TE) when the chain reaches 16 carbons in length. The TE domain has a groove structure close to the catalytic center that can accommodate long fatty acyl chain substrates. The groove is close to the amino terminus of the TE domain, which is linked to the ACP domain of FASN; this holds the growing acyl chains for scanning and release by the TE domain after reaching the optimal fatty acid chain length of 16 carbons (Chakravarty et al., 2004). Thus, the spatial organization of the TE domain is crucial for its function as a substrate-binding site in fatty acid synthesis. Maier (2008) reported that the TE domain of the human FASN gene is located after amino acid 2199. The c. $6545 \mathrm{~A}>\mathrm{C}$ (Asn $\rightarrow$ His) variation in pig FASN exon 39 found in this study is amino acid 2206, which is within the TE domain (Fig. 1).

Morris et al. (2007) found five SNPs in the cattle FASN gene and reported that they are associated with fatty acid content in adipose tissues and milk lipids. Furthermore, Zhang et al. (2008) report that the g.17924A $>\mathrm{G}$ variation in the TE domain of the cattle FASN gene affects C14:0, C16:0, and C18:1 fatty acid components in beef. There are also some reports indicating that SNPs in the cattle FASN TE domain significantly affect backfat thickness and IMF (Abe et al., 2009; Li et al., 2009; Kim et al., 2010a). It has also been reported that when marbling increases, the ratio of C18:1 increases along with changes in fatty acid composition ratios (Smith et al., 2006). Moreover, it is known that there is a positive correlation between C18:1 and meat flavor (Cameron and Enser, 1991).

We analyzed the association between: c. 265C $>\mathrm{T}$ (silent) and c.6545A $>\mathrm{C}$ (Asn $\rightarrow$ His) and meat quality and fatty acid composition traits. Highly significant associations were found between both polymorphisms and C16:1 and C18:1 content, which are MUFAs, in the KNP $\times \mathrm{YS} \mathrm{F}_{2}$ population (Table 4). Regarding the effect of c.265C $>\mathrm{T}$ (silent) genotype variation, individuals with the $\mathrm{CC}$ genotype had relatively higher $\mathrm{C} 16: 1$ and $\mathrm{C} 18: 1$ content than individuals with a CT or TT genotype. Regarding the effect of c.6545A $>C$ (Asn $\rightarrow$ His) genotype variation in the TE domain, individuals with the AA genotype had relatively higher $\mathrm{C} 16: 1$ and $\mathrm{C} 18: 1$ content than individuals with a $\mathrm{CA}$ or $\mathrm{CC}$ genotype. In addition, the linkage analysis between c.6545A $>\mathrm{C}$ (Asn $\rightarrow$ His) variation and meat quality traits revealed particularly interesting results in that significant effects on IMF were common to both the $\mathrm{KNP} \times \mathrm{YS} \mathrm{F}_{2}$ and $\mathrm{KNP} \times \mathrm{LR} \mathrm{F}_{2}$ populations. Moreover, individuals with the AA genotype had higher IMF content than individuals with a CA or CC genotype. In addition, when the $\mathrm{KNP} \times \mathrm{YS} \mathrm{F}_{2}$ and $\mathrm{KNP} \times \mathrm{LR} \mathrm{F}_{2}$ populations were combined and analyzed, the results revealed significant effects on IMF $(p<0.05)$. These results suggest that individuals with the A allele in c.6545A $>C$ (Asn $\rightarrow$ His) have high IMF, C16:1 and C18:1 content. The frequency of the A allele in the five pig breeds was examined through the analysis of the c.6545A $>\mathrm{C}$ (Asn $\rightarrow$ His) genotypes, and the results show that the frequency of the A allele was higher in the Korean native (1.00) and Berkshire $(0.73)$ breeds than in the Landrace $(0.50)$, Yorkshire $(0.40)$, or Duroc $(0.50)$ breeds. According to a report by Munoz et al. (2007), the A allele, which was fixed in $\mathrm{KNP}$, is also fixed in Iberian pigs.

This study revealed that the FASN gene is closely linked with variation of fatty acids that affect the meat quality of pigs and that the KNP breed has better meat quality and fatty acid composition than foreign breeds. These results provide an important basis for discovering genetic factors related to diverse and differential meat quality and fatty acid composition in different pig breeds. The results indicate that using KNP in improvement systems would be very beneficial in order to produce highgrade pork.

\section{Acknowledgement}

This work was supported by a grant entitled "Genetic improvement maximization of Korean native pigs using marker-assisted selection, and construction of commercial line production system" from the BioGreen 21 Program of the Korea Rural Development Administration.

\section{References}

1. Abe, T., Saburi, J., Hasebe, H., Nakagawa, T., Misumi, S., Nade, T., Nakajima, H., Shoji, N., Kobayashi, M., and Koba- 
yashi, E. (2009) Novel mutations of the FASN gene and their effect on fatty acid composition in Japanese Black beef. BioChem Genet. 47, 397-411.

2. Barrett, J., Fry, B., Maller, J., and Daly, M. (2005) Haploview: analysis and visualization of LD and haplotype maps. Bioinformatics 21, 263-265.

3. Bhuiyan, M., Yu, S. L., Jeon, J. T., Yoon, D., Cho, Y. M., Park, E. W., Kim, N. K., Kim, K. S., and Lee, J. H. (2009) DNA Polymorphisms in SREBF1 and FASN Genes Affect Fatty Acid Composition in Korean Cattle (Hanwoo). AsianAust. J. Anim. Sci. 22, 765-773.

4. Cannata, S., Engle, T., Moeller, S., Zerby, H., Radunz, A., Green, M., Bass, P., and Belk, K. (2010) Effect of visual marbling on sensory properties and quality traits of pork loin. Meat Sci. 85, 428-434.

5. Cameron, N. and Enser, M. (1991) Fatty acid composition of lipid in longissimus dorsi muscle of Duroc and British Landrace pigs and its relationship with eating quality. Meat Sci., 29, 295-307.

6. Chakravarty, B., Gu, Z., Chirala, S., Wakil, S., and Quiocho, F. (2004) Human fatty acid synthase: structure and substrate selectivity of the thioesterase domain. P. Natl. Acad. Sci. 101, 15567-15572.

7. Choi, K. M., Moon, J. K., Choi, S. H., Kim, K. S., Choi, Y. I., Kim, J. J., and Lee, C. K. (2008) Differential Expression of Cytochrome P450 Genes Regulate the Level of Adipose Arachidonic Acid in Sus Scrofa. Asian-Aust. J. Anim. Sci. 21, 967-971.

8. De, Smet. S., Raes, K., and Demeyer, D. (2004) Meat fatty acid composition as affected by fatness and genetic factors: a review. Anim. Res. 53, 81-98.

9. Folch, J., Lees, M., Sloane-Stanley, G. (1957) A simple method for the isolation and purification of total lipids from animal tissues. J. Biol. Chem. 226, 497-509.

10. Gallardo, D., Quintanilla, R., Varona, L., Diaz, I., Ramirez, O., Pena, R., and Amills, M. (2009) Polymorphism of the pig acetyl coenzyme A carboxylase á gene is associated with fatty acid composition in a Duroc commercial line. Anim. Genet. 40, 410-417.

11. Kim, E. H., Choi, B. H., Kim, K. S., Lee, C. K., Cho, B. W., Kim, T. H., and Kim, J. J. (2007) Detection of Mendelian and parent-of-origin quantitative trait loci in a cross between Korean native pig and Landrace I. growth and body composition traits. Asian-Aust. J. Anim. Sci. 19, 1702-1705.

12. Kim, S. S., Kim, J. R., Moon, J. K., Choi, B. H., Kim, T. H., Kim, K. S., Kim, J. J., and Lee, C. K. (2009) Transcriptional alteration of $\mathrm{p} 53$ related processes as a key factor for skeletal muscle characteristics in Sus scrofa. Mol. Cells. 28, 565-573.

13. Kim, S. W., Lee, J. H., Kim, J. H., Won, Y. S., Kim, N. S., and Kim, K. S. (2010a) Effect of the Fatty Acid Synthase Gene for Beef Quantity Traits in Hanwoo Breeding Stock. Korea. J. Anim. Sci. Tech. 52, 9-16.

14. Kim, S. W., Roh, J. G., Cho, Y. I., Choi, B. H., Kim, T. H., Kim, J. J., and Kim, K. S. (2010b) Development of Optimal Breeding Pigs Using DNA Marker Information. Genomics Inform. 8, 81-85.
15. Lepage, G. and Roy, C. (1986). Direct transesterification of all classes of lipids in a one-step reaction. J. Lipid. Res. 27, 114-120.

16. Li, S., Kim, S. W., Lee, J. J., Lee, J. H., Yoon, D., Kim, J. J., Jeong, Y. C., Jeon, S. H., Choi, J. W., Kim, N. S., and Kim, K. S. (2009) Characterization of the Bovine FASN Gene Variation for Carcass and Beef Quality Traits in Hanwoo. Korean. J. Anim. Sci.. Tech. 51, 185-192.

17. Li, X., Kim, S. W., Choi, J. S., Lee, Y. M., Lee, C. K., Choi, B. H., Kim, T. H., Choi, Y. I., Kim, J. J., and Kim, K. S. (2010) Investigation of porcine FABP3 and LEPR gene polymorphisms and mRNA expression for variation in intramuscular fat content. Mol. Biol. Rep. 37, 3931-3939.

18. Maier, T., Leibundgut, M., and Ban, N. (2008) The crystal structure of a mammalian fatty acid synthase. Science 321, 1315-1322.

19. Melton, S., Amiri, M., Davis, G., and Backus, W. (1982) Flavor and chemical characteristics of ground beef from grass-, forage-grain-and grain-finished steers. J. Anim. Sci. 55, 7787.

20. Moon, J. K., Kim, K. S., Kim, J. J., Choi, B. H., Cho, B. W., Kim, T. H., and Lee, C. K. (2009) Differentially expressed transcripts in adipose tissue between Korean native pig and Yorkshire breeds. Anim. Genet. 40, 115-118.

21. Morris, C., Cullen, N., Glass, B., Hyndman, D., Manley, T., Hickey, S., McEwan, J., Pitchford, W., Bottema, C., and Lee, M. (2007) Fatty acid synthase effects on bovine adipose fat and milk fat. Mamm. Genome 18, 64-74.

22. Munoz, G., Ovilo, C., Noguera, J., Sanchez, A., Rodriguez, C., and Silio, L. (2003) Assignment of the fatty acid synthase (FASN) gene to pig chromosome 12 by physical and linkage mapping. Anim. Genet. 34, 234-235.

23. Munoz, G., Alves, E., Fernandez, A., Ovilo, C., Barragan, C., Estelle, J., Quintanilla, R., Folch, J., Silio, L., and Rodriguez, M. (2007) QTL detection on porcine chromosome 12 for fatty-acid composition and association analyses of the fatty acid synthase, gastric inhibitory polypeptide and acetylcoenzyme A carboxylase alpha genes. Anim. Genet. 38, 639646.

24. Nestel, P., Clifton, P., and Noakes, M. (1994) Effects of increasing dietary palmitoleic acid compared with palmitic and oleic acids on plasma lipids of hypercholesterolemic men. J. Lipid. Res. 35, 656-662.

25. Oh, H., Kim, H., Yang, H., Lee, J., Joo, Y., and Kim, C. (2008) Comparison of meat quality characteristics between crossbreeds. Korean J. Food Sci. Ani. Resour. 28, 171-180

26. Smith, S., Witkowski, A., and Joshi, A. (2003) Structural and functional organization of the animal fatty acid synthase. Prog. Lipid. Res. 42, 289-317.

27. Smith, S., Lunt, D., Chung, K., Choi, C., Tume, R., and Zembayashi, M. (2006) Adiposity, fatty acid composition, and delta 9 desaturase activity during growth in beef cattle. $J$. Anim. Sci. 77, 478-486.

28. Stephens, M., Smith, N., and Donnelly, P. (2001) A new statistical method for haplotype reconstruction from population data. Am. J. Hum. Genet. 68, 978-989. 
29. Wood, J., Nute, G., Richardson, R., Whittington, F., Southwood, O., Plastow, G., Mansbridge, R., Da, Costa. N., and Chang, K. (2004a) Effects of breed, diet and muscle on fat deposition and eating quality in pigs. Meat Sci. 67, 651-667.

30. Wood, J., Richardson, R., Nute, G., Fisher, A., Campo, M., Kasapidou, E., Sheard, P., and Enser, M. (2004b). Effects of fatty acids on meat quality: a review. Meat Sci. 66, 21-32.

31. Zhang, S., Knight, T., Reecy, J., and Beitz, D. (2008) DNA polymorphisms in bovine fatty acid synthase are associated with beef fatty acid composition1. Anim. Genet. 39, 62-70.

(Received 2011.2.9/Revised 1st 2011.4.10, 2nd 2011.4.14/ Accepted 2011.4.14) 